\title{
"Talking Phonics for Autism": Developing A Multi-Purpose Touch Screen Technology Software Application Which Utilizes Sound Articulation Point to Teach Autistic Children
}

\author{
Noriha Basir1, ${ }^{*}$, Ameer Fuhaili Mohamad Hashim², Sharmini Abdullah ${ }^{1}$, Noor Asliza Abdul Rahim ${ }^{1}$, Masturah Sabri ${ }^{1}$, Afifah \\ Hanani Yusuf', Wan Norhaizar Harun' and Dipima Buragohain' \\ 1CIL,UniMAP,Malaysia \\ 2Ikom, UniMAP, Malaysia
}

\begin{abstract}
This paper aims to examine the potentials of the multi-purpose touch screen technology application which utilizes a sound articulation point software called "TALKING PHONICS FOR AUTISM"as an alternative method of teaching phonics to autistic children. "TALKING PHONICS FOR AUTISM"is developed via a collaborative effort between the Centre of International Languages (CIL) and the School of Human Development and techno Communication (iKOM), University Malaysia Perlis (UniMAP). The reading skills of autism children are developed intofive (5) levels ofMalay reading comprehension skills. The first level consists of open syllables - vowels and consonants. The following consecutivethree levels comprised of closed syllables. The fourth level introduces vocal sequence while the fifth level constitutes of Malay language loans. The Malay-language dialect phonological theory by Tajul Aripin Kassin (2000) which is based on Clements \&Keysher's (1980) Generative Booking Generic Fonology Model (CV) forms the theorectical framework of this paper.
\end{abstract}

\section{Introduction}

This paperwork discusses the development of bilingual phonic software for reading skills among autistic students. Autism belongs to a category of special needs children who have problems in terms of learning. The Department of Special Education (1995) defines children with learning disabilities as those who suffer from one or more of the original psychological processes involving the use of language, speech or writing that will result in imperfect ability to listen, speak, think, read, spell and make math calculations. The children with disabilities are those who have been identified and certified by clinicians as a disability that interferes with the learning process. Children with autism are usually detected since they are small. However, in most cases, they are detected while in school. Based on the observations in the classroom, autism children also have a short, short time span and not interested in theoretical learning. They prefer something that is practical and like to play with moving objects. However, these autistic children can be taught to speak and mingle with the community, rather than being marginalized. Consequently, the behaviour and emotion of these children should be seen from a positive point and these elements should be incorporated into the process of learning Malay and English which is specifically catered for them. The Ministry of Education is also constantly working on addressing children's problems in teaching and learning. Certainly, early actions and interventions can be channelled to problematic students which will help autistic children in Malaysia.

\section{Phonics studies in Malaysia}

Phonics studies in reading comprehension have been widely discussed by researchers in Malaysia. Tatat Hartati (1998: 64) explained that the Phonetic Reading Method has the same meaning as the Reading Method. The difference between the Phonetic Reading Method and the Reading Method is based on the sound of each letter. For example "B - Beh", "Z - zeh". Children are also given early exposure in knowing every letter and sound and sounding syllables. The next process is to combine these syllables into words. This Phonetic Reading method is suitable as one of the methods to teach reading Malay, because the Malay spelling system is phonemic and systematic. The disadvantages of this method are the same as the Reading Method. Children take a long time before being able proficiently read their own sentences and stories. Mazni (2007) in her action research entitled "Reading Skills Improvement Program" also suggested that the Phonetic Reading method be applied as a reading comprehension technique for school children. Techniques used include the merger of $\mathrm{CVCV}$, CVCVC and VCVC syllables. Tajul Aripin (2008) notes

* Corresponding author: sharminie.abdullah@gmail.com 
that the Phonetic Reading is a reading method which is hundred per cent based on the international standard phonetic sounds. In this case, he states that pupils are introduced directly with the phonetic sounds of a phoneme without introducing them to the sounds of the letters. He further explained that the reading method that combines the Reading Method and the Phonetic Reading Technique requires the students to understand both the sound strata of sound and the sound of letters and phonemes (the phonemes) which the letter $a$ is pronounced as [a], the letter $\mathrm{i}$ is pronounced as [i], the letter $\mathrm{e}$ is pronounced as [e] and [ə], the letter $\mathrm{u}$ is pronounced as $[\mathrm{u}]$ and $\mathrm{o}$ is pronounced as [o]. By using these two methods of reading, students are charged with the concept of recognizing and remembering a sound of the letters with their phonetic sounds which are unrelated to each other. The next discussion covers the aspects related to the development of this phonic software which is the Malay Language Phonology Theory by Tajul Aripin Kassin (2000). Similarly, the Strata Approach to Mastering Malay Language by Tajul Aripin Kassin (2012), the Reading Levels of Malay Language Skills, the Background and Animated Music Sounds proposed in this Phonic Software.

\subsection{Theory of Malay Phonology by Tajul Aripin Kassin (2000)}

\subsubsection{The Malay Language Phonological Words}

Tajul Aripin (2000) has explained that the Malay language phonology is the basic word (+ ending). That statement means, any phonological process that occurs in the base word and the term + ending is known as the phonological word. Based on the definition of the above phonological terms, the phonological process of Malay language such as the formation of sliding and geminating occurs in the phonological environment. Nevertheless, the process of gemination that occurs at the boundary of the suffix will not be discussed and not involved in this study. Meanwhile, other phonological processes such as insertion of glotis stops, vocal intermediates, assimilation, etc. are phonological processes that are applied beyond the phonological word domain. Therefore, the mastery of reading Malay language will be easier if the phonological word is applied in the teaching and learning of the Malay language of autism children. This phonological word can help teachers and students in determining when the glacial slide and stopping process comes in between two vocal sequences. For example, the word buah and juruukur. Surface sounds of the word are [bu.wah] dan [ju.ru./u.kur] not [bu./ah], [bu.ah] and [ju.ru.wu.kur] (Tajul Aripin, 2005: $11)$.

\subsection{Strata Approach to Mastering Malay Language Reading}

The strata approach to mastery of Malay reading was introduced by Tajul Aripin in 2012. He explains the approach of reading comprehension strata in the early stages of children with levels or strata; Input Representation (RI), Mental Representation (RM) and Phonetic Representation (RF). This statement is the same as the phonemic representation and the phonetic representation described by Zaharani (1998: 1094). He explains that the internal representation or input is an abstract representation that contains all the idiosyncratic information about the mention of morphemes or words in the utterance and this information is stored in the mental lexicon of the speaker. While surface or output representation is a concrete representation that manifests the actual mention of the morphemes or words in the utterance, and the information contained therein consists of idiosyncratic information as well as predictable information.According to Tajul Aripin (2012), the goal of mastery of reading the Malay language is to assess and test the extent to which the output of an input (process of spelling) is optimal or true. Output optimization according to him must be synchronous between RM and RF. Figure 2 below is the Early Childhood Reading Proficiency Strength Strata.

Figure 2: Strata of Proficiency in Reading the Malay Language

Source: Modified from the Strata of Mastery of Reading the Malay Language, Tajul Aripin, (2012)

The main purpose of the application of mastering Malay language skills by Tajul Aripin (2012) in this study is to see the syncreteness of the input or output of the word in Malay. This assessment will be used to describe the extent of reading Malay language among children with autism and the effectiveness of autistic children's Phonetic Reading Method.

\subsection{Malay language syllable structure (C)V(C)}

Malay Language syllable structure $(\mathrm{C}) \mathrm{V}(\mathrm{C})$ by Tajul Aripin (2000) is based on Generative Phonology by Clements \& Keysher in his thesis for Doctor in Phylosophy titled The Phonological Word in Standard Malay. This will be the basis in explaining the phonological phenomenon of the Malay language of autism children. Malay syllable structure is classified in language type IV, with these syllable structures: $\mathrm{CV}, \mathrm{V}$, CVC,VC. Various aspects of syllables such as syllable structures, combinations of segments that build syllables, syllable and word processing, and other related aspects can be explained through the model. Zaharani (2008) describes many of the phonological phenomena that apply in the language have been well-managed and solved through syllable theory analysis, for example phenomenon of vocal elongation, vocal insertion, consonant abortion, stress and others. 


\subsection{Articulation of speech sound in Malay Language}

Articulation/ of speech in Malay is vowel and consonant which is important in the preparation of Malay language reading skills among kids with austism in this phonic software.

\subsubsection{Vowel}

Nor Hashimah (2000: 38) states that vowel sounds involve air that blows out when producing this sound. Vowels are articulated in a manner that the articulators are far enough apart to allow the airflow to exit unhindered. John Lyons (1992: 88) explains that the vowels as sound produced with no obstacle for airflow through the oral cavity. Therefore, vowels are articulated in a manner different to that of consonants. He classifies this form of oral cavity as narrow, wide, front, back, round and upright. There are six vowels of Malay language that is $[\mathrm{e}, \leftrightarrow, \mathrm{a}, \mathrm{i}, \mathrm{o}, \mathrm{u}]$. Vowel /i/ known as high vowels and vowels $/ \mathrm{u} /$ are known as high back vowels. Whereas, the vowel /e/ is a narrow half-front vowel and the vowel /o/ is a narrow half-back vowel. Vowel /a/ is also known as broad back vowels (Tajul Aripin: 2005). It shows that the vowels play a very important role in the production of language sounds because without vocal a word cannot be formed and promulgated.

\subsubsection{Vokal Sequencing in Malay Language}

Vocal sequence exists when two or more vowels appear in sequence either in the beginning, in the middle, or at the end of the word. The sequential vowel presence in the Malay language will show two forms of vocal sound production, either by separate syllables [V.V] or diphthong [VV] (Tajul Aripin, 2009). Separate vocal sequences separated by syllables can often be seen in two forms, namely the vowel sequence with consonants and vowel sequences without any consonants (Tajul Aripin, 2009: 2). According to him, the presence of consonants in the vocal sequence is the result of the phonological process, either through the process of insertion of a consonant or the process of high vocal glide. Instead, a vowel sequence that does not allow any consonant to exist between the vocal sequence and allows the vocal sequence to sound as a separate syllables is known as hiatus. The vowel sequence symbolized as a phoneme and sounded in one syllable is also known as diphthongs (VV). M. Yunus Maris (1980: 40) explains the diphthongs sound refers to the pronunciation of two vowels released with only one breath. Nor Hashimah (2000: 41) states that the diphthong is a sequence of two vowels realized as one sound. The diaphragm sound is produced when the vowel sounds are present after the other vowel sound slides toward the first vowel without showing any volume peaks. The absence of peak volume during diphthong sound making makes it sounded like a single syllable.

\subsubsection{Consonant and Consonant Cluster}

Consonants are all sounds other than the vowels produced by restricting the airflow released through the lungs. The restriction can be made in the form of a full stop, partial stops or intermittent stops (Abdullah Hassan, 2006: 44). There are three different types of consonants in Malay. The consonant is the original consonant, loan, "gandingan dan rangkap". Tajul Aripin et.al (2005) states that there are 18 original Malay Language consonants. The consonants are /p, t, k, b, d, g, $\mathrm{s}, \mathrm{c}\left\lceil\right.$ I $, 1, \mathrm{r}, \mathrm{m}, \mathrm{n}, \mathrm{N}$, ) , h, j $\int, \mathrm{w}, \mathrm{y} /$. In phonetics, the symbols of the letters $n g, n y$ and $j$ are trascribed as [N], [)] and [jds] and a combination of two symbols $n g$ and ny are considered as one phoneme in Malay Language. Apart from the original consonant, Tajul Aripin et.al (2005) also adds that there are sounds of Arabic language and English language consonants that are present in Malay. The loan consonants are /f, z, $\otimes, \xi, \Sigma /$ symbolized in the Malay writing system as $f, z, g h, k h$ dan $s y$. In phonetics, the combination of two letters $g h$ $[\otimes], k h[\xi]$, and $s y[\Sigma]$ are considered as one phoneme.

Table 1: BMS Consomants Phonemes

\begin{tabular}{|c|c|c|c|c|c|c|}
\hline $\begin{array}{l}\text { Place of } \\
\text { articulation/ } \\
\text { Manner of } \\
\text { articulation }\end{array}$ & $\begin{array}{l}\text { Labi } \\
\text { al }\end{array}$ & $\begin{array}{l}\text { Alveaol } \\
\text { ar }\end{array}$ & $\begin{array}{l}\text { Dent } \\
\text { al }\end{array}$ & $\begin{array}{l}\text { Hard } \\
\text { palat } \\
\mathrm{e}\end{array}$ & $\begin{array}{l}\text { Soft } \\
\text { palat } \\
\text { e }\end{array}$ & $\begin{array}{l}\text { Glottal/lary } \\
\mathrm{nx}\end{array}$ \\
\hline $\begin{array}{l}\text { Plosive } \\
\text { Voiceless } \\
\text { Voiced }\end{array}$ & $\begin{array}{l}\mathrm{P} \\
\mathrm{b}\end{array}$ & $\begin{array}{l}\mathrm{t} \\
\mathrm{d}\end{array}$ & & & $\begin{array}{l}\mathrm{k} \\
\mathrm{g}\end{array}$ & $?$ \\
\hline $\begin{array}{l}\text { Plosive } \\
\text { Voiceless } \\
\text { Voiced } \\
\end{array}$ & & & & $\begin{array}{l}\mathrm{t} \int \\
\mathrm{d} 3\end{array}$ & & \\
\hline $\begin{array}{l}\text { Nasal } \\
\text { Voiced }\end{array}$ & $\mathrm{m}$ & $\mathrm{n}$ & & $\mathrm{n}$ & פ & \\
\hline $\begin{array}{l}\text { Fricative } \\
\text { Voiceless } \\
\text { Voiced }\end{array}$ & f & & $\begin{array}{l}\mathrm{s} \\
\mathrm{z}\end{array}$ & $\int$ & $\begin{array}{l}\mathrm{x} \\
\mathrm{y}\end{array}$ & $\mathrm{h}$ \\
\hline $\begin{array}{l}\text { Vibration/T } \\
\text { rill } \\
\text { Voiced }\end{array}$ & & $\mathrm{r}$ & & & & \\
\hline $\begin{array}{l}\text { Liquid } \\
\text { Voiced }\end{array}$ & & 1 & & & & \\
\hline $\begin{array}{l}\text { Half vocal } \\
\text { Voiceless }\end{array}$ & w & & $\mathrm{j}$ & & & \\
\hline
\end{tabular}

\subsection{Recommendations for Levels of Malay and English Reading Skills in Phonics Software.}

The author presents some suggestions on the reading skills of the Malay Language for Autistic Children.

\subsubsection{Vocal and Consonant Skill}

The suggested skill and level is to pronounce the vocal sounds based on Malay vocal sound articulation arrangement as in Table 2 below: 


\begin{tabular}{|ll|c|}
\hline \multicolumn{1}{|c|}{ Place of articulation } & $\begin{array}{c}\text { Sounding of } \\
\text { letters }\end{array}$ \\
\hline Middle & क \\
\hline Front & (high) & $\mathrm{i}$ \\
& (low) & $\mathrm{a}$ \\
\hline Back $\quad$ (high) & $\mathrm{u}$ \\
& (low) & $\mathrm{o}$
\end{tabular}

The suggested skill and level is to pronounce the consonant sounds based on Malay consonants articulation arrangement as in Table 3 below:

\begin{tabular}{|c|c|}
\hline Place of articulation & Sounding of letters \\
\hline $\begin{array}{l}\text { Voiceless Plosive } \\
\text { Voiced Plosive }\end{array}$ & $\begin{array}{lll}\text { p } & \text { t } & \text { k } \\
\text { b } & \text { d } & \end{array}$ \\
\hline $\begin{array}{l}\text { Voiced Plosive } \\
\text { Voiceless Fricative } \\
\text { Voiced Liquid } \\
\text { Voiced Trill }\end{array}$ & $\begin{array}{ll}\mathrm{g} & \\
\mathrm{s} & \mathrm{c} \\
1 & \\
\mathrm{r} & \end{array}$ \\
\hline $\begin{array}{l}\text { Voiced Nasal } \\
\text { Voiceless Fricative }\end{array}$ & $\begin{array}{lllll}\mathrm{m} & \mathrm{n} & \mathrm{ng} & \mathrm{ny} & \mathrm{h}\end{array}$ \\
\hline
\end{tabular}

\subsubsection{Open syllables Skill}

Open syllables skill is a combination of consonant sounds and vowel sounds as recommended in phonics software in Table 4 below:

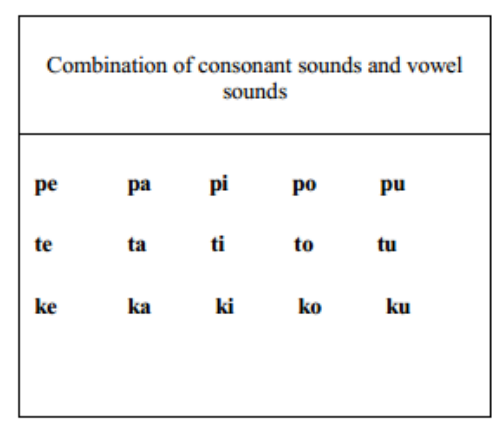

\subsubsection{Close Syllable Skill}

Close syllable skills level in the phonic software is as tabled in Table 4 below:

\begin{tabular}{|lllll|}
\hline pən & pan & pin & pun pon \\
tən & tan tin tun ton \\
kən & kan & kin & kun kon \\
bən & ban bin bun bon \\
dən & dan din dun don \\
\hline
\end{tabular}

\subsubsection{Vocal Sequence Skill}

Vocal sequencing skill of „aice, ,au“e and „oire that is recomended in phonic software is in Table 6 below:
pai pau poi
tai tau toi
kai kau koi
bai bau boi
dai dau doi

\subsubsection{Borrowed Words Skill}

Borrowed words skills recommended by the phonic software is as below (Table 7):

\begin{tabular}{|c|}
\hline tarikh \\
khat \\
khas \\
\hline
\end{tabular}

Next, the author recommends English Reading Skill in the phonic software.

\subsubsection{English Reading Skill}

\subsubsection{Vocal pronunciation skill}
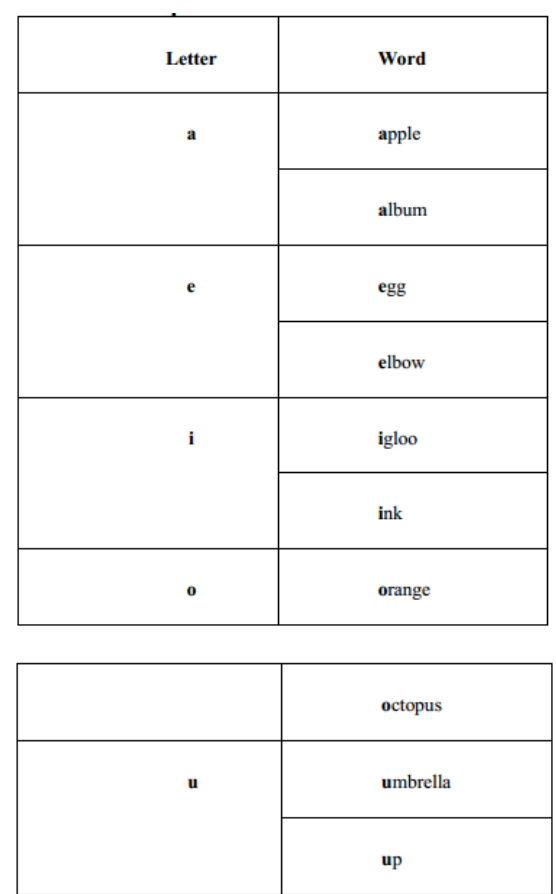

\subsubsection{Consonant pronunciation skill}




\begin{tabular}{|c|c|}
\hline \multirow{2}{*}{ Letter } & Word \\
\hline \multirow{2}{*}{ b } & Bird \\
\cline { 2 - 2 } & Book \\
\hline \multirow{2}{*}{ h } & Hand \\
\cline { 2 - 2 } & House \\
\hline \multirow{2}{*}{ J } & Jacket \\
\cline { 2 - 2 } & Jet \\
\hline
\end{tabular}

Therefore, in the software, simple English words and examples of pictures close to the world of autistic children is used to attract them to learn English.

\subsection{Selection of Attractive Drawings and Moving Elements}

To attract autistic children to master reading through phonics, selection of interesting pictures and moving image elements are used in this phonic software. Next the author displays and explains the main menus in this phonic software.

\subsubsection{Main menu in the phonic software "Talking Phonics for Autisme"}

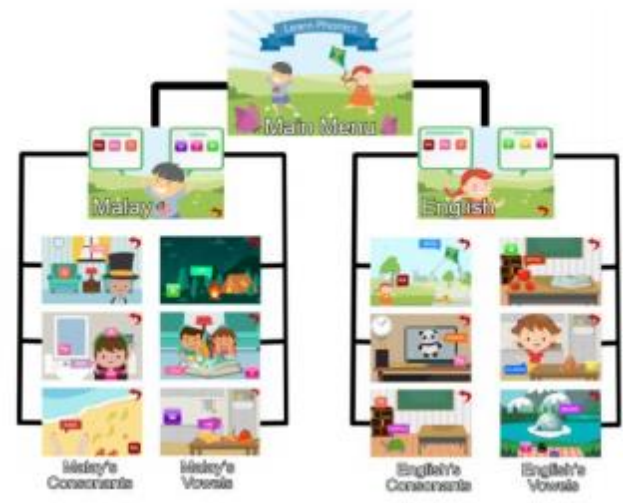

\subsubsection{Steps in Phonic Application}

(a) Choice of language in Menu : Phonics in Malay Language and Phonics in English

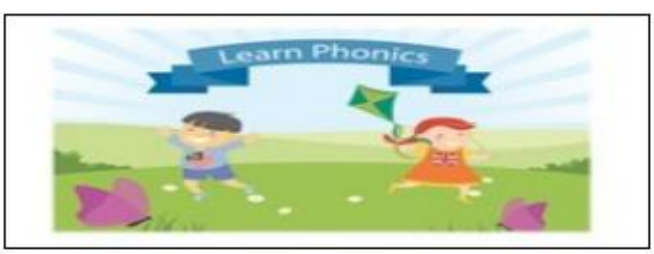

(b) After clicking on the Malay or the English Menu, user may select and choose to go to the Consonant or Vowel section.

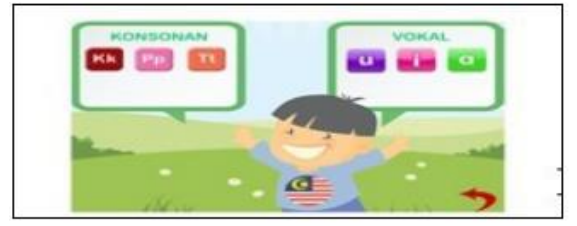

(c) Selection of the animated object chosen to accompany sounds and letters

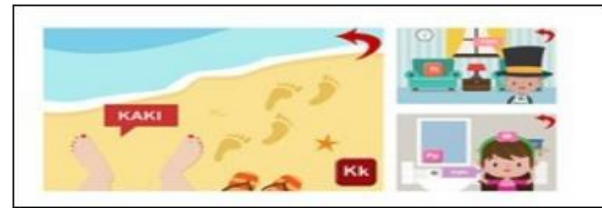

(d) Selection of animated pictures for the letter „, $U^{\text {ee }}$

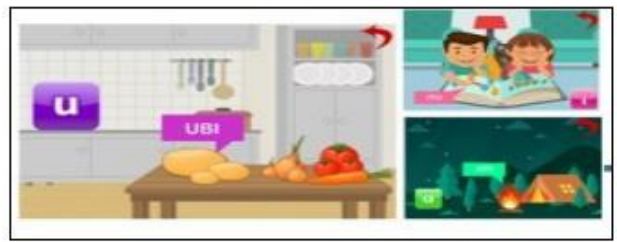

(e) English Menu

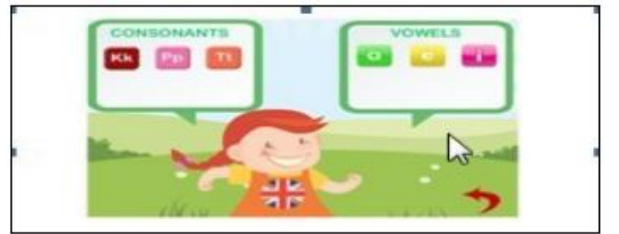

(f) For consonant , $\mathrm{K}^{\mathrm{ke}}$, the animated pictures given are to illustrate the word ,kitee and ,key

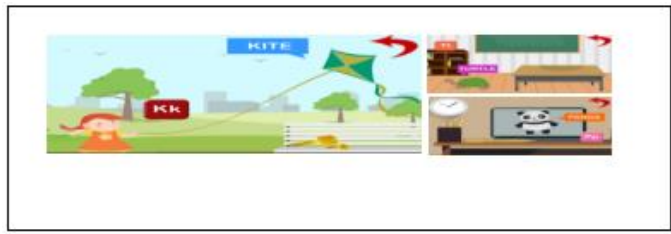

(g) Selection of animated pictures for each object

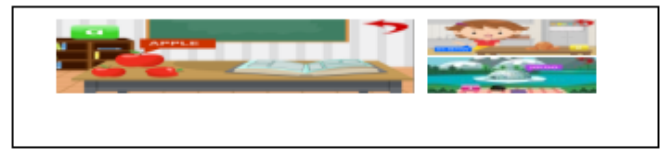

The selection of interesting and animated pictures is to attract autistic children and to foster their interest in browsing through the content of this phonics software, and thus to be able to learn how to read by following the recommended reading skills. 


\subsection{Songs and Music}

Songs and music are an important medium in everyday life, especially in children for a specific message. Therefore, the authors recommend that the song and music medium be applied in the teaching and learning approach of children to overcome the problem of reading Malay.

Abdullah Hassan (1987) stated that the approach was an attitude toward teaching and learning. The term approach in language teaching is a set of principles or assumptions related to language, language teaching and language learning. According to him, the approach is an overview of what the language really is, the way the language is derived, how it is born and understood, and the things that control the language. An approach will also be based on language theory, language teaching theory and specific language learning theories. While teaching according to Kamaruddin Husin (1993) is a complex process filled with various elements, namely student quality, intelligence, talent, interest, motivation, and so on. Therefore, the proper selection of songs and music should be applied in children's teaching and learning sessions. The content of songs that have interesting tones and rhythms are said to be able to deliver messages and positive values in children.

\subsection{Child Friendly Technology}

This Autism Phonic software has a child friendly interface. It can be installed on tablet and phone, aside from computers, as it is more accessible and convenient to be carried to almost anywhere as compared to software that can only be installed in computers. Touch screen technology used is also more suitable as children nowadays are very accustomed to and familiar with touch screen devices. Through one click, children will be able to surf through the applications that come with this phonic software. If before, only adults are familiar with technology, but now children especially special needs children will be able to enjoy and appreciate the world of technology and internet too.

\section{Conclusion}

In conclusion, the development of phonics software is very beneficial to the Ministry of Education in general and autism teachers across Malaysia in particular. The findings of the study can be utilized for the phonetic reading and learning process of autism children in Malaysia. The researcher also hopes that this study will be an inspiration to the Malay and English language autism teachers in identifying the appropriate teaching and learning methods for the students to master the reading skills of the Malay language more efficiently. Furthermore, the contribution of this study is to nurture and cultivate the interest of Malay and English language autism teachers to use effective techniques and methods in their teaching and learning process, especially in the application of phonetic reading methods based on certain levels of reading skills.

\section{References}

Abdullah Hassan. (1987). Isu-isu Pmbelajaran dan Pengajaran Bahasa Malaysia. Kuala Lumpur: Dewan Bahasa dan Pustaka. Kementerian Pendidikan Malaysia.

Abdullah Hassan. (2006). Morfologi. Kuala Lumpur: PTS Professional.

Clements, G.N. and Keyser, S.J. (1983). CV Phonology a Generative Theory of the Syllable: Cambridge. Massachusetts. London. England: The MIT Press.

Indirawati bt Zahid dan Mardian Shah bt Omar. (2006). Fonetik dan Fonologi. PTS Profesional Publishing Sdn. Bhd.

Kamarudin $\mathrm{Hj}$. Husin (1993). Sikap dan Motivasi Pelajar Terhadap Pembelajaran Bahasa Melayu. Kuala Lumpur : Kumpulan Budiman.

Lyons John; Ramli Salleh, Toh Kom Hoi. (1992). Bahasa dan Linguistik: SuatuPengenalan. Kuala Lumpur: Dewan Bahasa dan Pustaka

Mazni Othman (2007). Program Peningkatan Kemahiran Membaca: Sekolah Kebangsaan Kayan, Sitiawan, Perak.

Nor Hashimah Jalaluddin. (2000). Asas Fonetik. Kuala Lumpur:Dewan Bahasa dan Pustaka.

Tajul Aripin Kassin. (2000). The Phonological Word in Standard Malay. Tesis Doktor Falsafah. University of Newcastle at Newcastle Upon Tyne: United Kingdom.

Tajul Aripin Kassin. (2009). Kata di Gelanggang Bahasa, Esei-esei Penghargaan untuk Profesor Mashudi Kader. Pulau Pinang:Penerbit Universiti Sains Malaysia.

Tajul Aripin Kassin. (2012). Penguasaan Kemahiran Membaca Bahasa Melayu di Peringkat Awal Kanak-kanak. Dalam Seminar Jom membaca 1 Malaysia: 31 Mac 2012, 1-14.

Tatat Hartati. (1998). Keberkesanan Program Membaca Penguasaan Membaca Awal Kanak-kanak Pada Peringkat Pra Sekolah: Ijazah Sarjana Pendidikan Universiti Sains Malaysia. Pulau Pinang

Yunus Maris. (1980). The Malay Sound System. Kuala Lumpur: Fajar Bakti Sdn. Bhd.

Zaharani Ahmad (1998). Phonology and Morphology Interface in Malay : An Optimality Theoretic Account. Tesis Ph.D. Universiti of Essex. 